Perbal: Jurnal Pertanian Berkelanjutan

Volume 10 No.1 Februari 2022

ISSN 2302-6944,e-ISSN 2581-1649

\title{
RESPON PERTUMBUHAN DAN KEBERHASILAN SAMBUNG PUCUK TANAMAN KAKAO (Theobroma cacao L.) KLON M45 TERHADAP PERENDAMAN DAN PENYEMPROTAN POCL BIOTA
}

\author{
Response of Growth and Successful Shoot Grafting of Cocoa (Theobroma Cacao L.) Clone M45 \\ to Immersion and Spraying of Biota Liquid Organic Fertilizer \\ Mutmainnah $^{\left.1^{*}\right)}$, Rahman Hairuddin ${ }^{2)}$, Mei Kristiani Manulang ${ }^{3)}$ \\ ${ }^{1223)}$ Program Studi Agroteknologi Fakultas Pertanian Universitas Cokroaminoto Palopo \\ ${ }^{1 *}$ mutmainnahidayat@gmail.com
}

\begin{abstract}
ABSTRAK
Penelitian ini bertujuan untuk mengetahui bagaimana pengaruh dan dosis efektif POCL Biota terhadap pertumbuhan dan keberhasilan sambung pucuk tanaman kakao klon M45. Penelitian ini dilaksanakan di Lahan Percobaan I Fakultas Pertanian Universitas Cokroaminoto Palopo pada bulan Desember 2019 sampai April 2020. Metode yang digunakan dalam penelitian ini yaitu Rancangan Acak Kelompok dengan 6 perlakuan 4 ulangan sehingga terdapat 24 unit percobaan. Taraf yang digunakan yaitu P0 tanpa perlakuan (kontrol), P1 (1 ml POCL Biota/liter air perendaman entris dan penyemprotan bibit), P2 (2 ml POCL Biota/liter air perendaman entris dan penyemprotan bibit), P3 ( $3 \mathrm{ml}$ POCL Biota/liter air perendaman entris dan penyemprotan bibit), P4 (4 ml POCL Biota/liter air perendaman entris dan penyemprotan bibit), P5 (5 ml POCL Biota/liter air perendaman entris dan penyemprotan bibit). Hasil penelitian menunjukkan perlakuan P3 dengan dosis POCL Biota $3 \mathrm{ml} /$ liter air memberikan hasil terbaik pada diameter batang sambungan $(0,529 \mathrm{~cm})$, panjang tunas $(16,83 \mathrm{~cm})$, lebar daun $(8,33 \mathrm{~cm})$, dan panjang daun $(25,24 \mathrm{~cm})$. Sedangkan perlakuan P5 dengan dosis POCL Biota $5 \mathrm{ml} /$ liter air memberikan hasil terbaik pada parameter hari muncul tunas (6,37 hari), dan jumlah daun (15,62 helai). Hasil penelitian pemberian POCL Biota terhadap pertumbuhan dan keberhasilan sambung pucuk tanaman kakao memberikan pengaruh yang nyata terhadap beberapa parameter pengamatan hari muncul tunas, diameter batang sambungan, lebar daun, panjang daun, panjang tunas, sedangkan yang tidak nyata terdapat pada parameter jumlah daun.
\end{abstract}

Kata kunci: bibit kakao klon M45, POCL Biota, sambung pucuk

\begin{abstract}
This study aims to determine how the effect and the effective dose of POCL Biota on the growth and success of shoot grafting of M45 clone cocoa plants. This research was conducted in Experimental Field I, Faculty of Agriculture, Cokroaminoto University, Palopo on Desember 2019 until April 2020. The method used in this study was a randomized block design with 6 treatments and 4 replications so that there were 24 experimental units. The levels used were P0 without treatment (control), P1 (1 ml POCL Biota/liter of immersion water and spraying seeds), P2 (2 $\mathrm{ml}$ POCL Biota/liter of water immersion of Entries and spraying seeds), P3 (3 ml POCL Biota/liter Entries soaking water and spraying seeds), P4 (4 ml POCL Biota/liter water immersion Entries and spraying seeds), P5 (5 ml POCL Biota/liter water soaking Entries and spraying seedlings). The results showed that P3 treatment with a dose of POCL Biota $3 \mathrm{ml} /$ liter of water gave the best results on stem diameter $(0.529 \mathrm{~cm})$, shoot length $(16.83 \mathrm{~cm})$, leaf width $(8.33$ $\mathrm{cm})$, and leaf length $(25.24 \mathrm{~cm}) . \mathrm{cm})$. While the P5 treatment with a dose of POCL Biota 5ml/liter of water gave the best results on the parameters of the day of shoot emergence (6.37 days), and the number of leaves (15.62 strands). The significant effect on several parameters observed on the day of shoot emergence, stem diameter of the connection, leaf width, leaf length, shoot length, while the non-significant one was found in the number of leaves parameters.
\end{abstract}

Keywords: M45 clone cacao seeds, POCL Biota, shoot grafting 
Perbal: Jurnal Pertanian Berkelanjutan

Fakultas Pertanian Universitas Cokroaminoto Palopo

\section{PENDAHULUAN}

Kakao (Theobroma cacao L.) salah satu tanaman perkebunan yang sangat cocok di tanam di daerah tropis seperti wilayah Indonesia, karena tanaman ini dapat berbunga dan berbuah sepanjang tahun, sehingga menjadi sumber pendapatan harian atau mingguan bagi petani kakao. Tanaman kakao bersal dari daerah hutan hujan tropis di Amerika Selatan. Di daerah asalnya, kakao merupakan tanaman kecil di bagian bawah hutan hujan tropis dan tumbuh terlindungi pohon-pohon yang besar (Widya, 2008).

Kakao berperan sebagai salah satu komoditas perkebunan yang penting bagi perekomonian Indonesia, dikarenakan potensi kakao dalam penyediaan lapangan kerja dan penghasil devisa melalui kegiatan ekspor. Indonesia menduduki urutan ketiga dalam produksi kakao di dunia setelah Pantai Gading dan Ghana dengan produktivitas 1.315 .800 ton/tahun, serta luas total area perkebunan kakao di Indonesia dalam 5 tahun terakhir mencapai 1.462 .000 ha (Karmawati dkk, 2010).

Produksi kakao di Indonesia dari tahun 2016 sampai 2019 masing-masing 658.399, 590.684, 767.280 dan 783.978 ton. Hal ini menunjukkan bahwa produksi kakao di Indonesia berfluktuasi dimana pada tahun
2016 produksi mengalami kenaikan namun pada 2017 mengalami penurunan. Pada tahun 2018 kakao mengalami kenaikan produksi dan ditahun 2019 mengalami kenaikan produksi pula. Produksi kakao di Sulawesi Selatan dari tahun 2018 dan 2019 masing-masing 124.952 dan 118.775 ton. Berdasarkan data produksi kakao tersebut menunjukkan bahwa kakao mengalami kenaikan produksi, karena tingkat teknologi budidaya yang terus meningkat (Ditjenbun, 2019).

Salah satu usaha yang dapat dikelola untuk meningkatkan kualitas maupun kuantitas produksi kakao adalah dengan memperhatikan aspek dari budidaya tanaman kakao. Diantaranya adalah pengelolaan tanah, pemupukan, pemangkasan, pengendalian hama dan penyakit serta penyediaan bahan tanam yang layak untuk ditanam di lapangan yang nantinya akan menghasilkan bibit tanaman kakao secara maksimal (Triwanto, 2000).

Saat ini terdapat beberapa klon unggul kakao lindak yang dapat menjadi pilihan untuk dikembangkan, di antaranya adalah klon Sulawesi 01, Sulawesi 02, Sca 6, MCC 01, dan MCC 02/M45. Klon Sulawesi 01 dan 02 serta Sca 6 adalah klon generasi ketiga yang merupakan hasil introduksi, dan saat ini telah banyak dikembangkan di 
Indonesia melalui program Gerakan Peningkatan Produktivitas dan Mutu Kakao Nasional (Gernas). Potensi daya hasil ketiga klon tersebut masing-masing adalah 1,8-2,5; 1,8-2,75; dan 1,54 ton/ha, serta tahan dan agak tahan terhadap penyakit vascular streak dieback (VSD) (Susilo, dkk., 2015). Klon MCC 01 dan MCC 02/M45 adalah klon dengan produktivitas tinggi (3,672 dan 3,132 ton/ha), dan tahan terhadap hama penggerek buah (PBK), penyakit VSD dan busuk buah (Susilo, dkk., 2015).

Menurut Basri (2009) salah satu faktor keberhasilan dalam perbanyakan tanaman kakao dengan metode sambung pucuk dengan pemberian unsur hara yang cukup dan sesuai kebutuhan tanaman. Sebelum melakukan sambung pucuk terlebih dahulu diberikan perlakuan perendaman entres sebagai upaya meningkatkan kecepatan tumbuh tunas tanaman yang telah disambung. Peningkatan daya pertumbuhan tunas pada entres kakao tentu memerlukan unsur hara yang banyak untuk kelangsungan pertumbuhan dengan melakukan pemupukan melalui penyemprotan bibit tentu dilakukan suatu perlakuan yaitu pemberian pupuk organik cair lengkap (POCL) Biota pada entres dan bibit. Pupuk organik cair lengkap (POCL) Biota adalah pupuk organik terobosan terbaru teknologi unggulan yang ramah lingkungan untuk meningkatkan dan mempertahankan produktivitas. Pupuk ini diproduksi oleh Tri Harmoni Abadi tepatnya di Makassar yang telah di uji Laboratorium Sucofindo No. 3788408.

Pupuk organik cair lengkap (POCL) Super Biota merupakan pupuk organik yang dapat digunakan untuk semua jenis tanaman, khususnya tanaman perkebunan dan sangat baik untuk proses pembibitan. Pupuk organik ini dapat digunakan untuk memperkuat jaringan pada akar dan batang, berfungsi sebagai katalisator, sehingga dapat mengurangi pemakaian pupuk dasar hingga $50 \%$, mempercepat pertumbuhan akar tanaman, merangsang pertumbuhan tunas, dapat memperpanjang umur tanaman dan meningkatkan produksi panen 40\%-100\% (Abadi, 2015). Tujuan dari penelitian ini adalah untuk mengetahui pertumbuhan dan keberhasilan sambung pucuk tanaman kakao klon M45 terhadap perendaman dan penyemprotan POCL Biota dan mengetahui berapa konsentrasi perendaman entres dan penyemprotanbibit dengan POCL Biota yang tepat terhadap pertumbuhan dan keberhasilan tanaman kakao klon M45.

\section{METODE PENELITIAN}

Penelitian ini dilaksanakan di Lahan Percobaan I Fakultas Pertanian Universitas Cokroaminoto Palopo, Kelurahan 
Perbal: Jurnal Pertanian Berkelanjutan

Fakultas Pertanian Universitas Cokroaminoto Palopo

Rampoang, Kecamatan Bara, Kota Palopo

pada bulan 20 Desember 2019 sampai 14

April 2020.

\section{Metode Percobaan}

Penelitian ini disusun menggunakan

Rancangan Acak Kelompok (RAK) dengan

6 perlakuan di ulang sebanyak 4 kali sehingga diperoleh 24 unit satuan percobaan dan setiap ulangan terdiri dari 2 tanaman sampel sehingga terdapat terdapat 48 unit percobaan yang diamati. Adapun metode percobaan yang digunakan sebagai berikut:

$\mathrm{P} 0=$ Kontrol

P1 = $1 \mathrm{ml}$ POCL Biota/literair perendaman entres dan penyemprotan bibit

P2= $2 \mathrm{ml}$ POCL Biota/liter air perendaman entres dan penyemprotan bibit

P3= $3 \mathrm{ml}$ POCL Biota /literairperendaman entresdan penyemprotan bibit

P4= $4 \mathrm{ml}$ POCL Biota/liter airperendaman entresdan penyemprotan bibit

P5 = $5 \mathrm{ml}$ POCL Biota/liter air perendaman entres dan penyemprotan bibit

Data pengamatan kemudian dianalisis menggunakan sidik ragam (Analisis Sidik Ragam). Selanjutnya, data diuji lanjut dengan beda nyata jujur (BNJ) pada taraf $5 \%$.

\section{Persiapan Rumah Pembibitan}

Cara pembuatan rumah pembibitan terlebih dahulu memotong bambu berukuran
$200 \mathrm{~cm}$ sebanyak enam potong dan memotong bambu berukuran $250 \mathrm{~cm}$ sebanyak dua potong, serta memotong palang yang berukuran $350 \mathrm{~cm}$. Kemudian palang tersebut dihubungkan dengan tiang yang berukuran $250 \mathrm{~cm}$ untuk membentuk kerangka. Setelah kerangka terbentuk kemudian ditegakkan, selanjutnya tiang yang berukuran $200 \mathrm{~cm}$ ditegakkan masingmasing disisi kiri dan kanan tiang utama. Kemudian belah bambu menjadi dua bagian yang berukuran $200 \mathrm{~cm}$ sebanyak sepuluh bagian. Setelah belahan tersebut dipasang untuk menghubungkan sisi kiri dan kanan tiang utama dan sekaligus tempat dudukan plastik. Setelah semuanya terhubung selanjutnya memasang plastik dan daun kelapa sebagai atap dan memasang paranet disekeliling rumah penelitian untuk menghindari masuknya hewan ternak dan hama pengganggu lainnya.

\section{Penyediaan Bibit dan POCL Biota}

Bibit ditanam dan dipelihara dalam polybag berukuran 15 × $20 \mathrm{~cm}$ dengan media tanam yang digunakan adalah tanah. Bibit kakao yang digunakan pada penelitian ini adalah bibit lokal yang sudah berumur 3bulan dengan ciri yaitu pertumbuhan baik, sehat dan sedang bertunas. Kemudian persiapan POCL Biota yang digunakan yaitu produk yang sudah tersedia dalam bentuk 
kemasan botol yang diperoleh dari PT Harmony Abadi yang berada di Makassar pemesanan dilalukan secara online.

\section{Pemeliharaan Bibit}

Bibit kakao dalam polibag harus dipelihara dengan baik agar tumbuh dan sehat. Kegiatan pemeliharaan bibit meliputi penyiraman dan sanitasi gulma disekitaran polibag maupun di sekitar rumah pembibitan.

Penyiraman mutlak perlu dilakukan agar bibit tidak mengalami kekeringan. Saat musim kemarau, penyiraman dilakukan 2 kali sehari pada pagi dan sore hari, sedangkan saat musim hujan penyiraman disesuaikan dengan keadaan media tanam dalam polibag. Sanitasi gulma bertujuan untuk menjaga persaingan unsur hara, sehingga tanaman tumbuh sehat. Penyiangan di sekitaran salah satu usaha yang dapat dikelola untuk meningkatkan kualitas maupun kuantitas produksi kakao adalah dengan memperhatikan aspek dari budidaya tanaman kakao itu sendiri. Diantaranya adalah pengelolaan tanah, pemupukan, pemangkasan, pengendalian hama dan penyakit.

\section{Penyediaan Entres}

Entres berasal dari klon yang unggul dan juga berasal dari cabang kipas (plagiotrof). Entres yang baik harus mempunyai sifat sebagai berikut, yaitu: berwarna hijau kecoklatan, memiliki mata tunas, bebas dari serangan hama dan penyakit, mempunyai sifat unggul, berproduksi tinggi, tahan terhadap hama dan penyakit dan mempunyai kemampuan untuk menyesuaikan diri antara batang atas dengan batang bawah sehingga sambungan cocok (kompatibel).

\section{Aplikasi Perendaman Entres}

Tahapan dalam aplikasi POCL Biota untuk entres tanaman kakao yaitu, mempersiapkan POCL Biota di masingmasing tempat dengan konsentrasi/dosis yang berbedadengan campuran air. Selanjutnya entres tanaman kakao yang sudah disediakan kemudian dipotong dengan 3 mata tunaslalu direndam dimasing-masing konsentrasi dalam larutan POCL Biota selama 20 menit setelah entres direndam selanjutnya diangin-anginkan di kain bersih.

\section{Pelaksanaan Sambung Pucuk}

Penyambungan bibit dilakukan pada 48 bibit yang berumur tiga bulan yang dipilih atau telah diseleksi keunggulannya. Hal yang harus diperhatikan yaitu bagian pangkal sambungan harus dibersihkan dari debu dan tanah, pada potongan penyambungan tinggalkan 4-5 helai daun di bawah tempat sambungan pucuk, entres diambil dari klon terpilih dengan membuat 
Perbal: Jurnal Pertanian Berkelanjutan

Fakultas Pertanian Universitas Cokroaminoto Palopo

potongan sepanjang $10-15 \mathrm{~cm}$ atau mempunyai 2-3 mata tunas. Bagian pangkal disayat pada kedua sisinya sepanjang 2-3 $\mathrm{cm}$, sehingga bentuk irisannya seperti mata tombak. Selanjutnya batang atas dimasukkan kedalam belahan batang bawah kemudian diikat dengan tali plastik es yang sudah dibelah selebar $1 \mathrm{~cm}$. tali plastik ini ditarik pelan-pelan, sehingga panjangnya menjadi 2-3 kali panjang semula. Terbentuklah tali plastik tipis dan lemas pengikatan dilakukan dari atas kebawah Kemudian disungkup dengan plastik es dan ikat dibagian bawah. Setelah beberapa hari setelah penyambungan tunas akan keluar dan plastik sungkup dibuka (Karmawati, 2010).

\section{Aplikasi Penyemprotan Bibit}

Penyemprotan dapat dilakukan setelah sungkup sambungan telah dibuka memiliki 2-3 helai daun muda, penyemprotan dilakukan 1 minggu sekali setelah sungkup sambungan dibuka dan diulang sebanyak 8 kali. Adapun tahapan dalam mempersiapkan penyemprotan POCL Biota yaitu mempersiapkan POCL Biota dengan konsentrasi/dosis yang telah ditentukan dan dicampur dengan air selanjutnya di semprot menggunakan handsprayer ke bagian tanaman daun, batang dan akar dengan merata. Penyemprotan dapat dilakukan pada pagi hari jam 07:00
WIB sampai jam 10:00 WIB karena pada waktu tersebut mulut daun (stomata) membuka dengan sempurna sehingga tanaman dengan mudah menyerap pupuk dengan maksimal serta dapat mengurangi penguapan.

\section{Parameter Pengamatan}

Penelitian ini dilakukan pengamatan saat tunas mulai muncul dan pengamatan berikutnya dilakukan 2 minggu setelah aplikasi, pengamatan dilakukan sebanyak 5 kali dengan parameter pengamatan yaitu hari muncul tunas, diameter batang sambungan (cm), jumlah daun (helai), panjang tunas $(\mathrm{cm})$, lebar daun $(\mathrm{cm})$ dan panjang daun (cm).

\section{HASIL DAN PEMBAHASAN}

\section{Hari Muncul Tunas (Hari Setelah Sambung)}

Hasil rata-rata hari muncul tunas sambung pucuk tanaman kakao berpengaruh nyata pada pemberian POCL Biota terhadap perendaman dan penyemprotan sambung pucuk tanaman kakao. Gambar 1 menunjukkan hari muncul tunas terbaik pada P5 yaitu dangan rata-rata 6,37 HSS dengan dosis POCL Biota 5 ml/liter air, kemudian disusul P3 dengan dosis POCL Biota 3 ml/liter air dan P4 dengan dosis POCL Biota $4 \mathrm{ml} /$ liter air dengan rata-rata hari muncul tunas yang sama sebesar 6,75 HSS, 
kemudian selanjutnya P1 dengan dosis POCL Biota $1 \mathrm{ml} /$ liter air dan P2 dengan dosis POCL Biota $2 \mathrm{ml} /$ liter air dengan ratarata hari mucul tunas yang sama sebesar
7,87HSS. Berbeda halnya dengan perlakuan P0 (kontrol) yang menujukkan hari muncul tunas lebih lama yaitu dengan rata-rata 8,62 HSS.

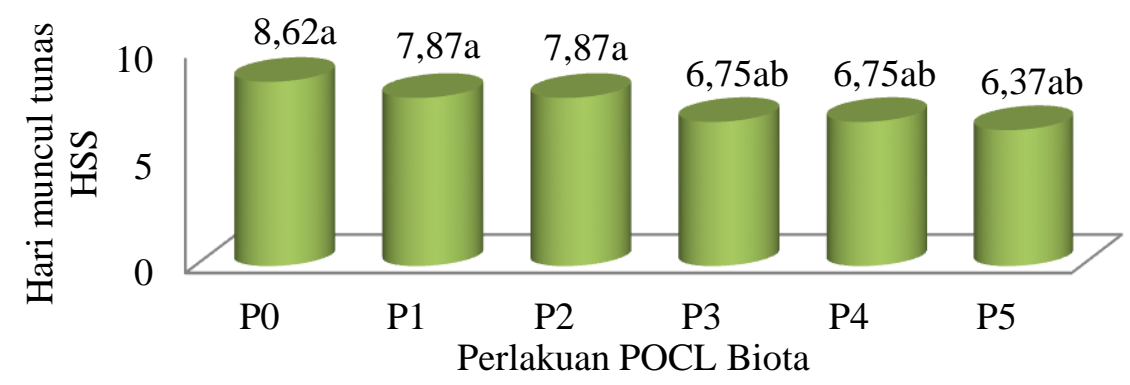

Gambar 1. Diagram rata-rata hari muncul tunas 6 HSS sambung pucuk tanaman kakao klon M45 terhadap perendaman dan penyemprotan POCL Biota. Angka yang diikuti oleh huruf yang sama menunjukkan perbedaan yang tidak nyata pada uji lanjut BNJ taraf 5\%.

Hal ini karena penggunaan POCL Biota yang mengandung unsur hara makro dan mikro serta zat perangsang tumbuh (ZPT) yang dapat memacu pertumbuhan tunas lebih cepat. Hal ini sesuai dengan pendapat Aini et al., (1999) menyatakan bahwa fisiologis hormon endogen (auksin) dapat membantu mendorong perpanjangan sel, pembelahan sel, diferensiasi jaringan xylem dan floem, dan pembentukan akar. Munculnya tunas merupakan awal dari pertumbuhan suatu tanaman.

\section{Diameter Batang Sambungan (cm)}

Berdasarkan gambar 2 diketahui bahwa rata-rata diameter batang sambung pucuk tanaman kakao sangat berpengaruh nyata pada pemberian POCL Biota terhadap perendaman dan penyemprotan sambung pucuk tanaman kakao. Diagram pada gambar 2 menunjukkan diameter batang sambungan terbaik pada P3 dengan dosis POCL Biota $3 \mathrm{ml} /$ lier air dengan rata-rata $0,65 \mathrm{~cm}$, kemudian disusul P4 dengan dosis POCL Biota $4 \mathrm{ml} /$ liter air dengan rata-rata 0,57 cm, kemudian P5 dengan dosis POCL Biota $5 \mathrm{ml} /$ liter air dengan rata-rata $0,55 \mathrm{~cm}$, kemudian P2 dengan dosis POCL Biota 2 $\mathrm{ml} /$ liter air dengan rata-rata $0,52 \mathrm{~cm}$, selanjutnya P1 dengan dengan dosis POCL Biota $1 \mathrm{ml} /$ liter air dengan rata-rata $0,48 \mathrm{~cm}$, sedangkan untuk hasil terendah terdapat pada P0 (kontrol) dengan rata-rata diameter batang $0,45 \mathrm{~cm}$. 
Perbal: Jurnal Pertanian Berkelanjutan

Fakultas Pertanian Universitas Cokroaminoto Palopo

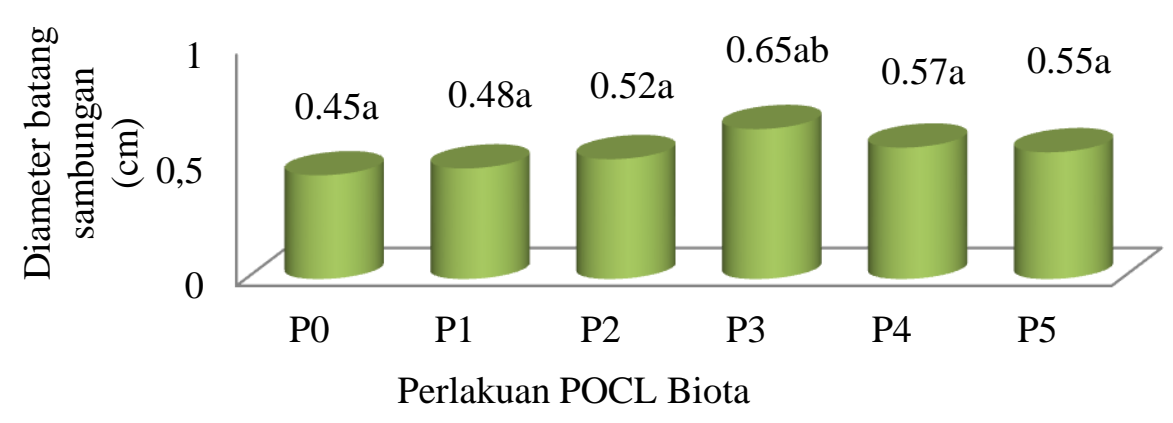

Gambar 2. Diagram rata-rata diameter batang sambungan 73 HSS sambung pucuk tanaman kakao klon M45 terhadap perendaman dan penyemprotan POCL Biota. Angka yang diikuti oleh huruf yang sama menunjukkan perbedaan yang tidak nyata pada uji lanjut BNJ taraf 5\%.

Menurut Tjitrosoepomo dan Sutarmi (2004), serapan unsur hara $\mathrm{P}$ dan $\mathrm{Ca}$ mendorong pembelahan sel-sel kambium. Sel-sel tersebut mengalami pembesaran dan berdiferensiasi membentuk xilem dan floem sekunder secara terus-menerus sehingga menyebabkan peningkatan diameter batang. Tingginya kandungan unsur hara N, P dan K sehingga dapat merangsang pertumbuhan diameter batang. Hal ini sesuai dengan Abadi (2015) yang menyatakan bahwa POCL Biota memiliki unsur hara makro dan mikro lengkap yang dapat berperan dalam memperkuat jaringan-jaringan akar, batang serta meningkatkan produksi.

\section{Jumlah Daun}

Berdasarkan gambar 3, jumlah daun sambung pucuk tanaman kakao tidak berpengaruh nyata terhadap perendaman dan penyemprotan POCL Biota. Diagram pada gambar 3 menunjukkan jumlah daun terbaik pada P3 yaitu dengan rata-rata 15,87 helai, kemudian disusul P5 dengan rata-rata 15,62 helai, kemudian P4 dengan rata-rata 14,12 helai, P0 dengan rata-rata 13,62 helai, selanjutnya P2 dengan rata-rata 13,50 helai, sedangkan untuk hasil terendah terdapat pada $\mathrm{P} 1$ dengan rata-rata 13,25 helai.

Hal ini diduga terjadi karena pupuk organik cair tersebut diaplikasikan melalui daun, sehingga memudahkan tanaman menyerap unsur hara yang diberikan melalui mulut daun (stomata) dan celah-celah kutikula. Hal ini sesuai dengan Sutanto (2002) yang menyatakan bahwa pupuk yang diberikan lewat daun diharapkan dapat diserap melalui mulut daun (stomata) dan celah-celah kutikula. Sehingga lebih cepat tersedia dan digunakan oleh tanaman untuk kebutuhan pertumbuhannya. 


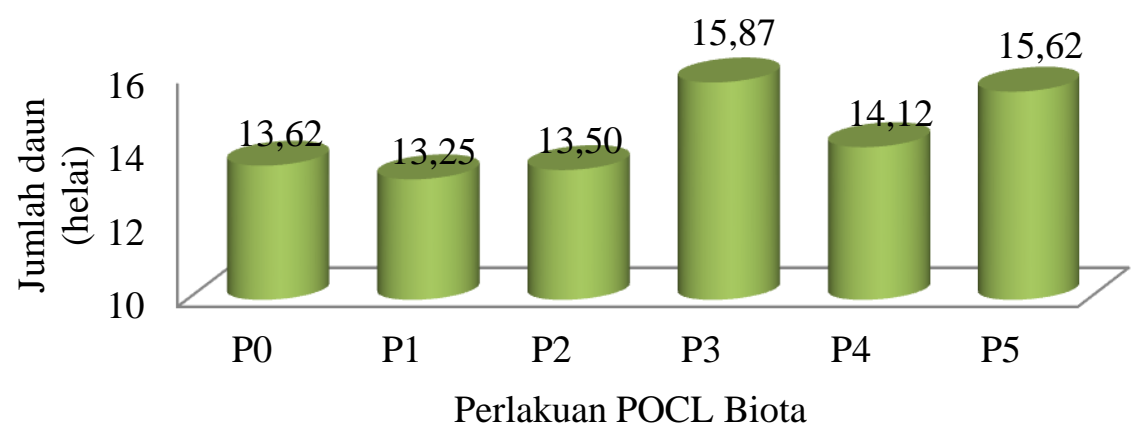

Gambar 3. Diagram rata-rata jumlah daun 73 HSS sambung pucuk tanaman kakao klon M45 terhadap perendaman dan penyemprotan POCL Biota.

\section{Panjang Tunas}

Diagram pada gambar 4 menunjukkan hasil rata-rata panjang tunas sambung pucuk tanaman kakao tidak berpengaruh nyata pada pemberian POCL Biota terhadap perendaman dan penyemprotan sambung pucuk tanaman kakao. Diagram dibawah menunjukkan perlakuan terbaik di P3 dengan dosis POCL Biota $3 \mathrm{ml} /$ liter air dengan rata-rata $22 \mathrm{~cm}$, kemudian P5 dengan dosis POCL Biota 5 $\mathrm{ml} /$ liter air dengan rata-rata $20,31 \mathrm{~cm}$, kemudian P2 dengan POCL Biota $2 \mathrm{ml} /$ liter air dengan rata-rata $19,43 \mathrm{~cm}$, selanjutnya P4 dengan POCL Biota $4 \mathrm{ml} /$ liter air dengan rata-rata 18,62 cm, dan P1 dengan POCL Biota $1 \mathrm{ml} /$ liter air dengan rata-rata 18,62 $\mathrm{cm}$, sedangkan untuk hasil terendah terdapat di P0 (kontrol) dengan rata-rata $17 \mathrm{~cm}$.

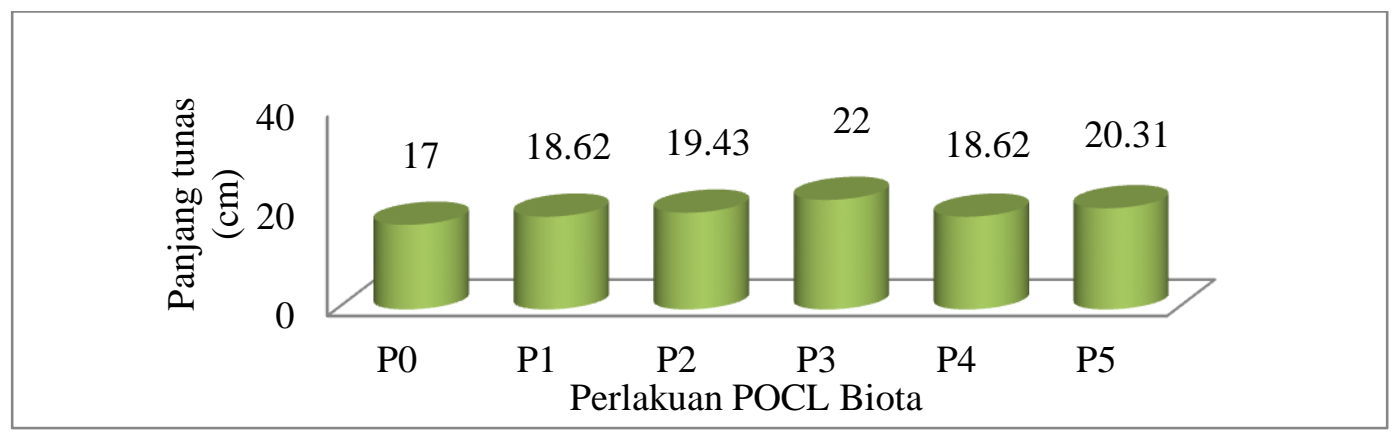

Gambar 4. Diagram rata-rata panjang tunas73 HSS sambung pucuk tanaman kakao klon M45 terhadap perendaman dan penyemprotan POCL Biota.

Faktor penting yang mempengaruhi percepatan laju pertumbuhan tunas adalah kondisi iklim, tanah, unsur hara dan jenis klon (Syafika dkk., 2014). Suhendi dkk
(2004) dalam Putu Sribawanti dkk (2016) menyatakan bahwa pertumbuhan tanaman yang baik dapat tercapai apabila unsur hara yang dibutuhkan dalam bentuk tersedia. 
Perbal: Jurnal Pertanian Berkelanjutan

Fakultas Pertanian Universitas Cokroaminoto Palopo

Seimbang dan dalam konsentrasi yang optimum serta didukung oleh faktor lingkungan dan genetiknya. Hal ini sesuai dengan Abadi (2015) yang menyatakan bahwa POCL Biota memiliki unsur hara makro dan mikro lengkap yang dapat berperan dalam memperkuat jaringanjaringan akar dan batang.

\section{Lebar Daun}

Diagram rata-rata lebar daun sambung pucuk tanaman kakao berpengaruh nyata pada pemberian perendaman dan penyemprotan POCL Biota. Diagram

dibawah menunjukkan perlakuan terbaik pada P3 dengan dosis POCL Biota $3 \mathrm{ml} / \mathrm{liter}$ air dengan rata-rata $11,37 \mathrm{~cm}$, kemudian P5 dengan dosis POCL Biota $5 \mathrm{ml} / \mathrm{liter}$ air dengan rata-rata $10,68 \mathrm{~cm}$, kemudian $\mathrm{P} 2$ dengan dosis POCL Biota $2 \mathrm{ml} / \mathrm{liter}$ air dengan rata-rata $10,12 \mathrm{~cm}$, selanjutnya $\mathrm{P} 4$ dengan dosis POCL Biota $4 \mathrm{ml} /$ liter air dengan rata-rata $9,75 \mathrm{~cm}$, kemudian $\mathrm{P} 1$ dengan dosis POCL Biota $1 \mathrm{ml} / \mathrm{liter}$ air dengan rata-rata $9,5 \mathrm{~cm}$, sedangkan untuk rata-rata hasil terendah terdapat di $\mathrm{P} 0$ (kontrol) dengan rata-rata $8,66 \mathrm{~cm}$.

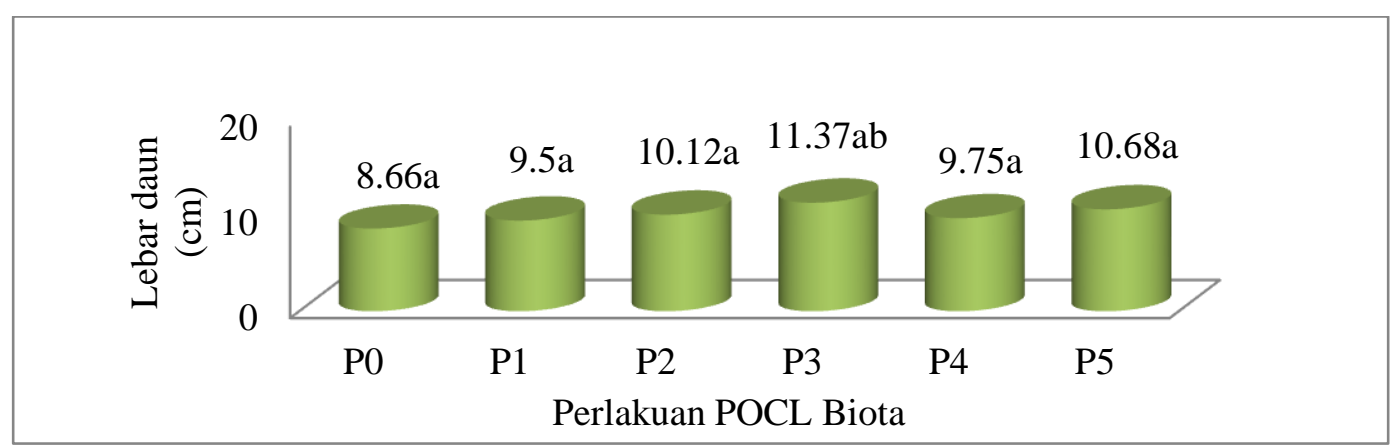

Gambar 5. Diagram rata-rata lebar daun 73 HSS sambung pucuk tanaman kakao klon M45 terhadap perendaman dan penyemprotan POCL Biota. Angka yang diikuti oleh huruf yang sama menunjukkan perbedaan yang tidak nyata pada uji lanjut BNJ taraf $5 \%$.

Hal ini diduga karena unsur hara nitrogen yang dibutuhkan tanaman mampu mendorong perkembangan vegetatif pada tanaman khususnya pada luas daun. Nitrogen sangat dibutuhkan oleh tanaman terutama pada fase vegetatif untuk pembentukan daun, batang, dan akar. Pembentukan daun yang banyak juga meningkatkan luas daun. Tanaman cenderung menginvestasikan sebagian besar nutrisi awal pertumbuhan mereka dalam bentuk penambahan luas daun, yang berakibat pemanfaatan radiasi matahari yang efisien untuk melakukan fotosintesis (Parto dkk, 2010 dalam Putu Sribawanti dkk, 2016). 


\section{Panjang Daun}

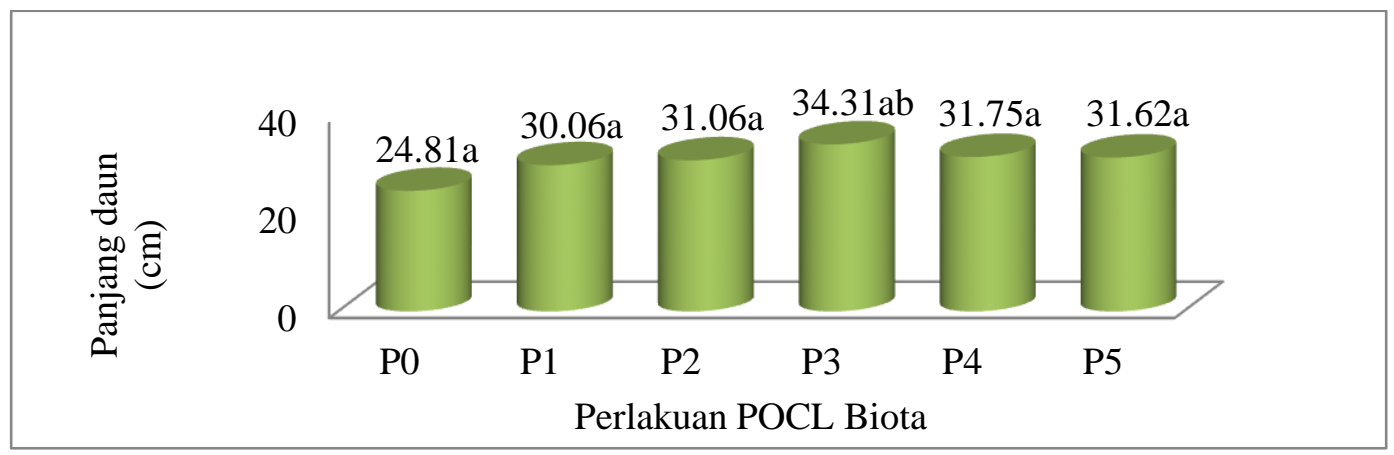

Gambar 6. Diagram rata-rata panjang daun 73 HSS sambung pucuk tanaman kakao klon M45 terhadap perendaman dan penyemprotan POCL Biota. Angka yang diikuti oleh huruf yang sama menunjukkan perbedaan yang tidak nyata pada uji lanjut BNJ taraf $5 \%$.

Berdasarkan diagram diatas hasil rata-rata panjang daun sambung pucuk tanaman kakao berpengaruh nyata pada pemberian POCL Biota terhadap perendaman dan penyemprotan sambung pucuk tanaman kakao. Diagram diatas menunjukan hasil bahwa pengaplikasian P3 POCL Biota dengan dosis POCL Biota 3 $\mathrm{ml} /$ liter air dengan rata-rata panjang daun mencapai $34,31 \mathrm{~cm}$, kemudian P4 dengan dosis POCL Biota $4 \mathrm{ml} /$ liter air dengan ratarata panjang daun $31,75 \mathrm{~cm}$, kemudian perlakuan P5 dengan dosis POCL Biota 5 $\mathrm{ml} /$ liter air dengan rata-rata $31,62 \mathrm{~cm}$ dan $\mathrm{P} 2$ dengan dosis POCL Biota $2 \mathrm{ml} / \mathrm{liter}$ air dengan rata-rata 31,06 $\mathrm{cm}$, kemudian $\mathrm{P} 1$ dengan dosis POCL Biota $2 \mathrm{ml} / \mathrm{liter}$ air dengan rata-rata $30,06 \mathrm{~cm}$. Sedangkan untuk hasil terendah terdapat di P0 (kontrol) dengan rata-rata panjang daun $24,81 \mathrm{~cm}$.

\section{KESIMPULAN}

Respon pertumbuhan dan keberhasilan sambung pucuk tanaman kakao terhadap perendaman dan penyemprotan POCL Biota berpengaruh nyata pada parameter pengamatan hari muncul tunas, diameter batang sambungan, lebar daun, panjang daun, sedangkan yang tidak berpengaruh nyata pada parameter jumlah daun. Dosis terbaik POCL Biota terhadap pertumbuhan dan keberhasilan sambung pucuk tanaman kakao yang memberikan hasil terbaik yaitu P3 dengan dosis $3 \mathrm{ml} /$ liter air untuk parameter diameter batang sambungan hasil rata-rata $0,65 \mathrm{~cm}$, lebar daun hasil rata-rata $11,37 \mathrm{~cm}$, panjang daun hasil rata-rata $34,31 \mathrm{~cm}$, jumlah daun hasil 
Perbal: Jurnal Pertanian Berkelanjutan

Fakultas Pertanian Universitas Cokroaminoto Palopo

rata-rata 15,87 helai, panjang tunas hasil rata-rata $22 \mathrm{~cm}$.

\section{DAFTAR PUSTAKA}

Aini,N.,M. Tampubolon dan G. Dadan. (1999). Pengaruh Macam Ruas batang dan Konsentrasi Rootone $\mathrm{F}$ terhadap Keberhasilan dan Pertumbuhan Stek Bambu Jepang (Dracaena godseffiana) Kultivar Mawar. Jurnal Hortikultura.11(109):48-58.

Basri, Z. (2009). Kajian Metode Perbanyakan Klonal pada Tanaman Kakao. Media Litbang Sulteng. 2 (1) : 07-14.

Ditjenbun. (2019). Statistik Perkebunan Indonesia 2017. Departemen Pertanian, Direktorat Jenderal Perkebunan. Jakarta.

Karmawati, E. (2010). Pengendalian Hama Helopeltis spp pada Tanaman Jambu Mete Berdasarkan Ekologi; Strategi dan implementasinya. Pengembangan Inovasi Pertanian 3 (2) : 102-119.

Karmawati, E., dkk. (2010). Budidaya dan Pasca Panen Kakao. Pusat Penelitian dan Pengembangan Perkebunan. Bogor. 94 Halaman.

Parto, Y., Yernelis, S. dan Teguh, A. (2010). Pengaruh Penggunaan Pupuk Urea dan Aplikasi Herbisida Pra-Tumbuh terhadap Pertumbuhan Bibit Karet (Hevea brasiliensis Muell.Arg.) dan Gulma di Pembibitan. J. Agrovigor. 5 (2): 96-99.

Sribawanti, P., Lapanjang. M. L., Made. U. (2016). Pertumbuhan Bibit Sambung Pucuk Dini Kakao (Theobroma cacao L.). Klon Sul-1 dan Sul-2 yang diberi Pupuk Organik Cair Berbeda Konsentrasi. Jurnal Agroteknologi 4 (3): 267-273.

Susilo, A.W., Anita-Sari, I., \& Imran. (2015). Yield performance of locally selected cocoa clones in North Luwu. Pelita Perkebunan, 31 (3), 152-162.

Sutanto, D. (2002). Pertanian Organik (Menuju Pertanian Alternatif dan Berkelanjutan). Kanisius. Jakarta.

Syafika, M., Yati, R. dan Karyudi. (2014). Pengaruh Pupuk Daun terhadap Hasil dan Komponen Hasil Pucuk Tanaman Teh (Camellia Sinensis (L.) O. Kuntze Var. Assamica (Mast kitamura). Pusat Penelitian Teh dan Kina. 1 (1):53-54.

Tjitrosomo dan H. S. Sutarmi. (2004). Botani Umum. Bandung Angkasa.

Tri Harmoni Abadi. (2015). Pupuk Organik Cair Lengkap (POCL) Biota Plus. Laboratorium BBTP No : SP 103 P/LBPTP/ IV/ 2015.

Tri Harmoni Abadi. (2015). Pupuk organik cair super biota plus.http://www.triharmoniabadi.com diakses pada tanggal 10 Mei 2020.

Triwanto. (2000). Pengaruh Konentrasi Larutan Zat Pengatur Tumbuh Plant Stimuland dan Interval Pemberian terhadap Pertumbuhan Bibit Kakao (Theobroma Cacao L.). http:diglib.sith.itb.ac.id/go.php?id=jiptu mm-gdl-res-2000-joko-forestry. Diakses pada tanggal 04 Mei 2020.

Widya, Y. (2008). Budidaya Tanaman Cokelat. Tim Bina Karya Tani. Bandung. 